\title{
Maintenance of French in Ontario: Is Education in French Enough?
}

\author{
Raymond Mougeon, Michael Canale/OISE
}

In a recent study, Churchill (1976) examined the historical processes which have led to the development of what he refers to as the contemporary "Franco-Ontarian Educational Rennaissance". In this study, Churchill pointed out that a decade ago, after years of struggle, Franco-Ontarians were granted the right to education in French. This led notably to the establishment of a system of French language high schools which complemented the unofficial system of elementary French language schools already extant in many Franco-Ontarian communities. Churchill expressed hopes that the legalization and subsequent development of French language schools would help to counteract the loss of French language which characterizes the Franco-Ontarian population at large (Allard 1974, Castonguay 1974, Mougeon \& Hébrard 1975) and especially younger FrancoOntarians (Vachon 1973, Léon 1976, Mougeon, Canale \& Bélanger 1978 and Mougeon \& Canale 1978).

In this paper, we would like to show that while education in French may be necessary in Ontario to counteract the replacement of French by English, it is not of itself sufficient. We will argue that other factors such as francophone concentration, institutional support for French, the control of Ontario's economy by Anglo-Ontarians, etc. also play a key role in the maintenance or gradual disappearance of French among Franco-Ontarians. We will also try to show that difficulties directly related to French language schooling in Ontario may also contribute to French language replacement. We will conclude by indicating what steps might be taken to improve the status of French in Ontario and to counteract its replacement by English.

\section{Francophone concentration}

According to the 1976 Census, Ontario included 462,190 people who claimed French as a mother tongue and 6,457,645 people who claimed English as a mother tongue ${ }^{1}$. These figures indicate a predominance of anglophones over francophones. At a regional or community level, however, francophone concentration varies greatly and can be much higher than the provincial mean. There are three main Ontario regions where one finds substantial numbers of francophones. These are: South Eastern Ontario (the rural counties of PrescottRussell, Stormont-Dundas and Glengarry), where francophones constitute a strong majority ( $80 \%$ and over) at the county and community level; South Western Ontario, where francophones constitute a small minority both at the regional and community level (Toronto $1.6 \%$, Welland $16.1 \%$, Windsor $5.9 \%$, etc.); and Northern and Mid Northern Ontario, where French speakers are outnumbered (North Bay 16.3\%, Sudbury 29.6\%), predominate (Hearst $81.3 \%$, 
Sturgeon Falls $74.2 \%$, Rayside $60.6 \%$ ) or are a strong minority (Timmins $38 \%$, Cochrane $43 \%$ ).

In his study of the 1961 Canadian Census data, Lieberson (1971) established clearly that outside the Province of Quebec, in communities where Canadians of French extraction were on a par with or outnumbered by English-speaking Canadians, the former group included many bilingual individuals and many English mother tongue individuals who had been linguistically "assimilated". This was confirmed for Ontario by Allard (1974) Castonguay (1974) and Mougeon \& Hébrard (1975) on the basis of the 1971 Census returns. These last authors also noted that in Ontarian communities where francophones were not a numerical majority, sizable proportions of French mother tongue Canadians reported communicating mostly or entirely in English at home. The questions on language use in the home were an innovation of the 1971 census. It appears that the local level of Franco-Ontarian concentration is related to the proportion of bilingual Franco-Ontarians and to French language retention in a given community.

\section{French Language Schooling}

Given this general trend, the question comes to mind of the impact of French language schooling on the language behaviour of the students who receive it. If such schooling has a strong positive effect on the language behaviour of the students, one can expect that, irrespective of francophone concentration at the community level, the students who are schooled in French will show a strong preference for communication in French. If it has a weak or marginal effect, one can expect the language behaviour of the students to reflect the language-use patterns of the Franco-Ontarian communities in which they live. Having carried out sociolinguistic surveys in Franco-Ontarian schools in each of the provincial regions mentioned above, we are in a position to report findings bearing out our hypothesis. We will report here on the intragroup language use of FrancoOntarian secondary school students outside the classroom but on the school premises (corridors and playground). We assume that most of these students were schooled in French at the elementary level ${ }^{2}$.

In Welland (16\% francophones), we observed that almost all of the students attending the French language high school communicated among themselves exclusively in English in the setting mentioned above. In Sudbury (29\% francophones) and Timmins (38\% francophones), we observed that the students attending the French language high schools showed a strong preference for intragroup communication in English although they were observed to communicate in French occasionally. In Rayside (60\% francophones) the French language high school students communicated mostly in French. Finally, in Hawkesbury (84\% francophones), located in the Prescott-Russell county, the francophone students attending the local high school communicated almost all of the time in French. Unlike the other schools, the high school in Hawkesbury has a linguistically-mixed student population. More specifically, it houses a small number of English mother tongue students who receive education in English. Communication across language groups, however, is carried out almost always in French.

The above data indicate a correspondence between the local level of francophone concentration and the extent of intragroup use of the French language among French language high school students. Furthermore, on the basis of other observations carried out in the above-mentioned Franco-Ontarian communities, we find the intragroup language use of the francophone students to 
be in keeping with the general patterns of language use which characterize these communities. Thus, focussing on the two extremes of francophone concentration, one hears in Welland relatively little French on the streets and in the stores located in the French district; in Hawkesbury, however, the reverse in true - little English is used on the streets and in the stores. With respect to the question raised above, our findings suggest that in Ontario, French language schooling does not seem to have had a strong effect on the student's use of the French language; or, to put it differently, French language schooling does not appear to be strong enough to counterbalance French language shift among Franco-Ontarian students in communities where francophones are not a numerical majority.

In earlier papers (Mougeon and Canale 1977 \& Mougeon, Canale and Bélanger 1978), we hypothesized that the mastery of French by Franco-Ontarian students in a given community is related to the level of francophone concentration in that community. We arrived at such a hypothesis after a short preliminary examination of a sample of tape-recorded interviews carried out with elementary and secondary school Franco-Ontarian students in some of the communities mentioned above. Briefly this examination revealed that the spoken French of students from predominantly French-speaking communities was closer to the varieties of French spoken by monolingual Quebec City students than was the spoken French of students from minority Franco-Ontarian communities. The differences involved notably the amount of borrowing from English, switching to English, structural simplification, etc.

Thanks to a survey now in progress in seven communities where francophones are outnumbered by anglophones, we should be in a better position to explore further the relationship that seems to exist between Franco-Ontarian concentration and the use and mastery of French by Franco-Ontarian students locally. The survey will focus on communities which range from a maximum level of francophone concentration of $40 \%$ (Cornwall) to a minimum of $1.6 \%$ (Toronto). In these communities we will gather data on the students' spoken French, utilization of French, present day and intended use for French, and attitudes towards standard French, and we will attempt to interrelate such data. We are currently of the opinion that the relationship between local francophone concentration and younger Franco-Ontarian students' mastery and use of French holds true generally. However, we do not think that Franco-Ontarian concentration alone can account for younger Franco-Ontarians' use and mastery of French; nor do we think that in any given Franco-Ontarian community, there won't be individuals who fail to correspond to the general local pattern. The survey mentioned above should hopefully shed new light on those questions.

The possible influence of local francophone concentration on younger Franco-Ontarian students' mastery of French further suggests that French language schools may not play a preponderant role in the Franco-Ontarian students' retention of French. In other words, it appears that French language schools located in predominantly English-speaking Ontarian communities will experience more difficulties in having their students reach a satisfactory level of French language mastery than French language schools serving Franco-Ontarian majority communities.

\section{Support for French in the Public Sector}

We have argued elsewhere (Mougeon, Canale and Bélanger 1978) that the extent to which French is or is not used in private or public institutions in Ontario affects 
the structural (lexical, syntaxic, stylistic, etc.) development of the variety of French used by Franco-Ontarians. We would like to argue here that the level of institutional support for French may also have a bearing on the maintenance of French among Franco-Ontarians. More specifically, the more French language services there are in the private and public sector; the more opportunities FrancoOntarians will have to use or be exposed to French (not only as beneficiaries of those services but also as employees in the public and private institutions) and the more convinced younger and older Franco-Ontarians may become of the "officialness" and usefulness of French in their community and Ontario at large. Thus a probable result of increased institutional support for French would be increased willingness on the part of Franco-Ontarians to maintain French.

Having made the above point, it appears relevant to examine the extent to which French language services are available in the two sectors, public and private. Let us begin with the public and semi-public sector. It includes such institutions as government offices and agencies (at the federal, provincial and local levels), government-controlled companies, and the media.

To begin with the media, as far as French language television is concerned, it has only recently been installed in outlying regions or in regions where francophones constitute small minorities (1971 in Toronto and 1977 in Windsor). In these regions program reception has not always been problem free ${ }^{3}$. Furthermore, some minority communities are still without a French language TV station (e.g. Pembroke). In major urban centres or in cities located next to the U.S. border, the only local French language TV station has to compete with a large number of English language stations. Another problem which further limits the competitiveness of Ontario French language TV is the context and orientation of its programs. In this respect one should mention that Franco-Ontarian adults often complain that Radio Canada devotes too little air time to the political, economic or cultural affairs of Franco-Ontarians (most of the programs originate from Quebec) and that the programs are often too intellectual and dull. ${ }^{4}$ Furthermore, during our sociolinguistic surveys in Ontario French language schools, several students reported having difficulty at times in understanding the variety of French used on the Radio Canada Television network. In this respect one should bear in mind that, on Radio Canada, most movies, series, and plays that are of American origin are often dubbed in European varieties of French, whose informal registers can be markedly different from Canadian French. Finally most of the students interviewed in our surveys indicated a strong preference for American TV productions. Such a preference may be the result of the sophisticated programming and marketing strategies of the American TV industry and the fact that new American programs (e.g. "Battlestar Galactica", "The Incredible Hulk") had to appear in English long before they are dubbed in French. ${ }^{5}$

Given the above, it is not surprising that surveys carried out among FrancoOntarians in Welland and Cornwall and among elementary school FrancoOntarian children in the Carleton-Ottawa area revealed that in Cornwall $30 \%$ of the francophone population watches French TV most or all of the time while in Welland only $22 \%$ do so. In the Carleton-Ottawa area, $20 \%$ of the students reported watching French TV most or all of the time. Moreover the Cornwall and Welland surveys also revealed that younger Franco-Ontarians are less interested in watching French TV than older Franco-Ontarians - in Cornwall only $15 \%$.

In our opinion the question of French television in Ontario illustrates the important point that mere availability of an institution functioning in French does 
not mean its potential users will make full use of it. With French television, its inability to meet the needs of its users limits its impact on French language maintenance in the Franco-Ontarian population at large and especially among younger Franco-Ontarians.

French language radio is confronted with problems similar to the ones mentioned above - recently or not yet established stations and programs inadequately adapted to local reality. However, owing to the slow and incomplete creation of the CBC network of French Radio, several local private stations (notably in Northern Ontario) have filled the gaps. Such stations tend to hire local people and broadcast in a language variety which is closer to that spoken by the local population. It would be interesting to find out whether such stations are more listened to than French CBC Radio stations.

Similar problems are to be found as well in the written media.There is only one French language daily newspaper in Ontario, Le Droit published in Ottawa. As it is only sold in Ottawa and the Ottawa region, it has a limited impact on the Franco-Ontarian population at large. Furthermore, the local and regional news included in Le Droit tends to be concerned with communities which are located in the Quebec part of Ottawa region and may not be of interest to the average Franco-Ontarian. By contrast, French language regional newspapers constitute real avenues for Franco-Ontarian self-expression; but they are to be found only in areas where there are substantial numbers of Franco-Ontarians. They appear weekly and are rarely sold at street corners or local stores. These three factors limit the impact of a medium which has the obvious merit of answering some of the special needs of the Franco-Ontarian population.

To conclude, French language media in Ontario could have a more sizeable impact on French language maintenance than it presently does.

Let us briefly examine the status to which French has been assigned in Ontario's provincial and federal administrations. We will start with the provincial administration. The multiplicity of complaints and requests addressed to the various Ontarian ministries give one a general indication of the low level of governmental support for French language services. Such requests or complaints emanate from organizations such as the ACFO (Ontario French Canadian Association) or the FFHQ (Federation of Francophones outside Quebec). Even in a predominantly French-speaking area such as Cornwall and its neighbouring villages, a recent survey (Breault, Harkin, Lalonde \& Poirier 1976) revealed that more than 30 percent of the residents of this area were not satisfied with the level of French language services provided in the local institutions under provincial control. A recent report addressed to the Ministry of Health and Welfare (Dubois 1976) about the general need for French language services in Ontario's public hospitals gives one another indication of the Ontarian government's reluctance to provide a minimum level of French language services in the institutions which it controls. Such reluctance is all the more regrettable since it may have an impact on the quality of services provided by institutions which have much importance for the average Ontarian (e.g. Ontario's public hospitals). More disturbing is the fact that in localities where Franco-Ontarians constitute numerical minorities, provincially-controlled institutions provide no (or very little) French language services (cf. FFHQ 1977). And it does not look as if the provincial government is willing to rectify this situation, since it recently decided to limit the provision of French language services to provincial institutions in localities where large numbers of francophones are to be found. Given what has been said earlier about the weakness of French in communities where Franco-Ontarians are a numerical 
minority, one may wonder whether such a decision will not contribute to precipitating the erosion of French in such localities. We would argue that if the Ontarian government really wanted to ensure the maintenance of French in Ontario, it should provide not only a minimum level of French language services in such communities but increased levels of such services. Finally, we fear that the provincial government's recent refusal to support a bill aimed at making French an official language in Ontario will reinforce the feelings of doubt that many Franco-Ontarians have about the value of French in Ontario (Chaperon-Lor 1974, Mougeon 1978). Such feelings may represent an added motivation for Franco-Ontarians to assimilate into the English-speaking Ontarian majority.

In the institutions which come under the control of the federal government, the French language seems to have a relatively higher status. In Toronto (a city with only $1.6 \%$ of francophones), one can now be served in French at the Central railway station and at the customs at the airport. In other federal institutions in Toronto though (e.g. the post office), one finds an almost total absence of French language services. More generally, the annual reports compiled by the Commissioner of Official Languages should serve as a reminder that the federal government has not yet reached its intended goal of allowing Canadians to be served in the official language of their choice (English or French) in all federal institutions. The Commissioner's reports contain an impressive number of complaints, mostly about lack of French language services. However, numerous as the complaints may be, they fail adequately to reveal the dearth of French language services in institutions controlled by the federal government: for example, the absence of French language services in Toronto's post offices were directed to the Commissioner's office (cf. Spicer 1975). Given what we have said about the post office, the Commissioner's report underrepresents the need for French language services in the federal institutions. It appears unlikely, however, that French language services available in federal institutions in Ontario will increase. On the contrary, they will probably decline as a result of the federal government's decision to phase out (within the next four years) its program of language training for civil servants. Thus the federal government's inability to provide sufficient levels of French language services to Franco-Ontarians may constitute yet another factor contributing to the demise of French in Ontario.

\section{Support for French in the Private Sector}

In the private sector of Ontario, French has a much lower status than in the public or semi-public institutions examined above, even in localities where there are substantial numbers of Franco-Ontarians. A survey carried out in the industrial and commercial sphere of Welland revealed that only one of Welland's many big factories provided some measure of French language services. In this factory, where there are 40 percent French-speaking workers, job-related regulations and announcements are posted in English, Hungarian and French. ${ }^{6}$ In the town of Mattawa (55\% francophones), the local mill, which employs a majority of francophone workers, functions almost entirely in English. In the mining industry of Timmins, English is used almost exclusively, in spite of the large numbers of francophones.

In the commercial and advertising sectors, there is a similar predominance of the English laguage, even in communities with substantial numbers of francophones. Thus, in the cities of Timmins, Kapuskasing, Sudbury and Welland one is struck by the scarcity of advertising billboards, posters, signs, flyers written in French. But the responsiblity for this situation does not entirely 
rest with the anglophone population, since, as was revealed by our socio-linguistic surveys, not all francophone businessmen from these localities seem to be convinced of the necessity and utility of promoting French in their respective businesses.

It may be hypothesized here that the low status assigned to French in Ontario's private sector has a more detrimental influence on French language maintenance than in Ontario's public or semi-public sectors (the major source of employment in the province). Such a low status may have many younger FrancoOntarians seriously question the utility of acquiring, maintaining and handing down a language which contributes only marginally to the socioeconomic betterment of Ontarians. ${ }^{7}$

To conclude our examination of the usage and status of French in Ontario public and private sectors, we can enumerate the main consequences that inadequate or low levels of French language services in these sectors have the following consequences: overall reduction in the exposure to the French language; overall reduction in the use of the French language; overall depreciation of the utilitarian value of the French language; and an increase in the number of Franco-Ontarians who question the utility of maintaining French.

\section{Educational Problems - Types of School and Language Usage}

Let us examine now two sets of problems which are directly linked with French language schooling in Ontario and which may also contribute to the linguistic assimilation of younger Franco-Ontarians. The first set concerns the principle of French language schooling per se and how it is implemented in the Ontarian reality. We have seen earlier that ten years ago the provincial parliament legalized French language education in Ontario and that such a measure brought about the creation of a set of new French language secondary schools. However for several reasons (notably opposition from the anglophone members of certain school boards, - see Churchill 1976, 1978 for more details) in several localities FrancoOntarian parents have to send their children to mixed schools housing anglophone and francophone students. Here Churchill (1978) argues convincingly that such schools would not necessarily have a negative effect on French language maintenance among younger Franco-Ontarians if they provided the same level and quality of French language schooling as that being offered in non-mixed French language schools. Unfortunately such is not the case. Churchill (1978) provides statistics which show that mixed secondary schools offer significantly fewer courses in French than non-mixed schools. Furthermore, in mixed secondary schools, the students are free to select their courses in French or English (when they are available in both languages). As a result, towards the end of secondary school, many francophone students take some or all of their courses in English. On the basis of such data and other data pointing out the inadequacy of French language services offered by mixed schools, Churchill (1978) hypothesized that in contrast to non-mixed secondary schools, mixed secondary schools contribute to the linguistic assimilation of their Frenchspeaking pupils. We do not yet have any data which would support Churchill's hypothesis. However, since our new survey on the use of French in minority Franco-Ontarian communities includes communities where there are both mixed and non-mixed secondary schools, we may be later in a position to examine the issue raised by Churchill (1978).

The fact that most mixed schools result from Anglo-Ontarian opposition to the creation of non-mixed French language schools in certain school districts does 
not necessarily mean that all Franco-Ontarians are opposed to mixed schools (see Churchill 1978). In fact in certain localities, some Franco-Ontarian parents choose to send their children to the local mixed secondary school so that the children receive a bilingual type of education (as opposed to a French language education). Several studies - Comeau (1971), Chaperon-Lor (1974) and Mougeon (1978) - have shown that the concept of a bilingual education is supported (sometimes quite actively - see Mougeon, 1978) by substantial proportions of Franco-Ontarian parents in various localities. It is our opinion that support for bilingual education by Franco-Ontarian parents is a more or less direct consequence of the inferior status assigned to French in Ontario. In this respect, Mougeon (1978) provides data that indicate the supporters of bilingual education are mostly working class and lower middle class Franco-Ontarian parents and that such support is indicated by these parents' sensitivity to the high utilitarian value of English in Ontario.

With respect to the influence of mixed schools on the linguistic assimilation of younger Franco-Ontarians, one may speculate about the extent of such influence. If the hypothesis proposed earlier about the marginal influence of French language education upon French language maintenance among younger FrancoOntarians is correct, one may likewise hypothesize that mixed schools play only a marginal role in the linguistic assimilation of younger Franco-Ontarians. We do not believe there is an obvious answer to this question and we think it should be carefully examined.

Finally, let us examine the second set of problems mentioned above. It concerns the teaching of French language arts in Ontario French language schools. Except for recent attempts by officials from the Ministry of Education to incorporate notions related to language variation in the official guidelines, the teaching of French as a first language in Ontario still adheres to a clearly normative approach. Such an approach is based partly on a negative perception of the informal (non standard) French used by Franco-Ontarian students, which many educators still fail to recognize as a language. Canale \& Mougeon (1978), on the basis of results of several descriptive studies devoted to Franco-Ontarian French (mostly their own studies), tried to demonstrate that Franco-Ontarian students' French constitutes an authentic linguistic system. Although such a system differs from standard French, it nevertheless belongs to the "family" of contemporary or past dialects of the French language. In the same study, the authors hypothesized that in communities where Franco-Ontarians are a numerical minority, a rejection or condemnation of the Franco-Ontarian students' French may not only have a negative effect on the students' self-perception but also contribute to discouraging the students from maintaining French. In such communities a more efficient pedagogical approach for the teaching of French might be based on a recognition of the authority of Franco-Ontarian French and an enrichment of the student's competence.

\section{Conclusion}

We hope that the preceding analysis has demonstrated that French language maintenance in Ontario does not depend only on French language schooling. Other factors may. play a more or less important role in the maintenance or disappearance of French in the Franco-Ontarian population. In a study devoted to the restoration of Irish, Macnamara (1971) arrived at similar conclusions. The author remarked that given the predominance of English in the key sectors of Irish society, Irish language schooling proved incapable of turning out students who 
had a good knowledge of Irish and who used it actively. Such a finding is clearly in keeping with the above analysis inasmuch as it shows that schooling in a language which is little used outside the school is not sufficient to assure the maintenance of that language among its younger learners.

To conclude this paper, we would like to outline some of the steps that might be taken to assure the maintenance of French in Ontario. To achieve such a goal, we should: increase the level of French language services in the institutions which come under the provincial and federal jurisdiction and which are located in all of the communities where Franco-Ontarians are present; encourage private institutions which hire francophone employees to allow such employees to use French on the jobs and to provide services in the French language when sizable proportions of francophone employees are present: urge the French $\mathrm{CBC}$ to reexamine the content and orientation of its programs and the varieties of French it uses when broadcasting in Ontario; make sure that in all localities FrancoOntarian parents be given the opportunity to send their children to non-mixed French language schools; help Franco-Ontarian educators to explore alternative approaches for the teaching of French as a first language.

\section{Notes}

${ }^{1}$ Mother tongue was defined as the first language learned and still understood by the respondent on census day.

${ }^{2}$ The chances that a child who has been schooled in English at the elementary level will be sent to a French language school are low, except in the case of parents who handed down French to their child but were unable (or unwilling) to send him to a French language elementary school.

${ }^{3}$ To mention an example before the completion of the $\mathrm{CN}$ communications tower in Toronto residents of the Niagara Peninsula who did not have Cable TV could not receive French language TV programs.

${ }^{4}$ It is perhaps interesting to mention that there seems to exist a similar kind of dissatisfaction with Radio Canada in Acadia. Thus in a report to the CRTC the "Sociéte Nationale des Acadiens", declared that Radio-Canada contributed to the assimilation of francophones (Le Droit, 3 June, 1977) in New Brunswick, Nova Scotia and Prince Edward Island by providing programs which are both culturally and linguistically alienating. The recent creation of Radio-Acadie is probably related to such dissatisfaction.

II should be pointed out that the CBC network is not alone in having considerable difficulty in competing against the American industry, much of the problems outlined above also apply for the Canadian movie industry.

${ }^{6}$ This and the following information was gathered during sociolinguistic surveys carried out in Welland and in the communities mentioned below.

7The present government of Quebec seems to be convinced of the importance of the status of French in the private sector, since it recently passed a French language charter which contains many clauses aimed at insuring that French becomes the predominant language in this sector.

\section{References}

Allard, P. Les Franco-ontariens et l'assimilation. Le Droit, 31 October 1974.

Bréault, M., Harkin, M., Lalonde, M. \& Poirier, G. Enquête sur les habitudes de lecture et de communication des francophones de Cornwall et la région. Report prepared for the Ontario Ministry of Education, 1976. 
Canale, M. \& Mougeon, R. Problèmes posès par la mesure du rendement en français des élèves franco-ontariens. In B. Cazabon, (Ed.), Langue maternelle, langue première de communication. Institut franco-ontarien, Laurentian University, Sudbury, 1978. Published also in Working Papers on Bilingualism, No. 16.

Castonguay, C. Dynamique de l'assimilation. Le Droit. 15 March 1974.

Chaperon-Lor, D. Une minorité s'explique. O.I.S.E.: Toronto, 1974.

Churchill, S. National linguistic minorities: the Franco-Ontarian educational renaissance. Prospects, Vol. 5, No. 3, 1976.

Churchill, S. Costs: French language instructional units. Report prepared for the Ontario Ministry of Education, 1978.

Comeau, $P$. Les facettes d'un système scolaire: rapport préliminaire soumis au Comité de recherche de l'Association des commissions des écoles bilingues de l'Ontario. Mimeo, Social Science Faculty, University of Ottawa, Ottawa, 1971.

Dubois,J. Pas de problème? Report from the Comité d'action sur les services de santé en langue française. AFCO, Ottawa, Ontario, 1976.

FFHQ Les héritiers de Lord Durham. Vol. 2 (the ACFO report). Ottawa: Fédération des Francophones Hors Québec 1977.

Léon, P. Attitudes et comportements linguistiques: problèmes d'acculturation et d'identité. Cahier de Linguistique, No. 61976.

Lieberson, S. Language and ethnic relation in Canada. New York: Wiley, 1971.

Macnamara, J. Successes and failures in the restoration of Irish. In Rubin, J. \& Jernudd, B. eds. Can language be planned. The University Press of Hawaii, 1971.

Mougeon, R. Bilinguals vs French language schools: a study of parental expectations among Franco-Ontarians. Paper presented at the 9th World Congress of Sociology held in Uppsala, Sweden (14-19 August), 1978.

Mougeon, R., and Canale, M. Maintien du fraçais par les jeunes étères franco-ontariens de Welland. In B. Cazabon (Ed.), Langue maternelle, langue première de communication. Institut Franco-Ontarien, Laurentian University, Sudbury, 1978.

Mougeon, R. \& Canale, M. Minority language schooling in English Canada: The case of the Franco-Ontarians. Paper read at the CERA meeting: Learned Societies Conference, Fredericton, New Brunswick, (June) 1977.

Mougeon, R., Canale, M. \& Bélanger, M. Rôle de la société dans l'acquisition et le maintien du français par les élèves franco-ontariens. Canadian Modern Language Review. Vol. 34, No. 3, 1978 .

Mougeon, R. \& Hébrand, P. Aspects de l'assimilation linguistique dans une communauté Francophone de l'Ontario. Working papers on bilingualism, No. 5, 1975.

Spicer, K. Commissaire aux langues officielles: rapport annuel. Information Canada: Ottawa, 1975.

Vachon, J. A proposal for a structural analysis of the language development of the child as a base for learning a mother tongue. Report prepared for the Ontario Ministry of Education, 1973. 